\title{
Additions to the rust fungi of South Africa
}

\section{Journal Article}

Author(s):

Berndt, Reinhard; Wood, Alan R.

Publication date:

2012-05

Permanent link:

https://doi.org/10.3929/ethz-b-000160616

Rights / license:

In Copyright - Non-Commercial Use Permitted

Originally published in:

Mycological Progress 11(2), https://doi.org/10.1007/s11557-011-0764-z 


\title{
Additions to the rust fungi of South Africa
}

\author{
Reinhard Berndt • Alan R. Wood
}

Received: 7 February 2011 /Revised: 15 April 2011 /Accepted: 19 April 2011 / Published online: 28 May 2011

(C) German Mycological Society and Springer 2011

\begin{abstract}
This paper presents new species, combinations, national reports and host records for the South African rust fungi (Uredinales/Pucciniales). Endophyllum mpenjatiense on cf. Hibiscus sp. (Malvaceae), Phakopsora combretorum (anamorph Uredo combreticola) on the new host Combretum apiculatum (Combretaceae) and Uredo sekhukhunensis on Ziziphus mucronata (Rhamnaceae) are described as new species. Dietelia cardiospermi and E. metalasiae are proposed as new combinations to replace Aecidium cardiospermi on Cardiospermum halicacabum (Sapindaceae) and A. metalasiae on Metalasia spp. (Asteraceae), respectively. Four species are new records for South Africa: Crossopsora antidesmae-dioicae on Antidesma venosum (Euphorbiaceae), Phakopsora ziziphi-vulgaris on Z. mucronata, and Uromyces cypericola and Puccinia subcoronata, both on a new host, Cyperus albostriatus (Cyperaceae). The record of P. subcoronata is the first one from outside the New World. Puccinia scirpi is reported as a possible addition to the South African rust fungi. New host records and observations are presented for Pucciniastrum agrimoniae that is recorded on two new host genera and species, Cliffortia odorata and
\end{abstract}

Taxonomical novelties: Dietelia cardiospermi (Cooke) R. Berndt \& A. R. Wood. Endophyllum metalasiae (Syd. \& P. Syd.) A. R. Wood \& R. Berndt. Endophyllum mpenjatiense A. R. Wood \& R. Berndt. Phakopsora combretorum A. R. Wood \& R. Berndt. Uredo sekhukhunensis R. Berndt \& A. R. Wood.

R. Berndt $(\bowtie)$

Institute of Integrative Biology (IBZ), ETH Zurich,

CHN D-37, Universitätstr. 16,

8092 Zürich, Switzerland

e-mail: reinhard.berndt@env.ethz.ch

A. R. Wood

Weed Pathology Unit, ARC-Plant Protection Research Institute,

P. Bag X5017, Stellenbosch 7599, South Africa
Leucosidea sericea (Rosaceae), Uromyces cypericola whose urediniospores are described for the first time, Phakopsora stratosa in that spermogonia and Uredo-like aecia were discovered, and for Sphaerophragmium dalbergiae in that characters of the urediniospores are re-evaluated. A lectotype is selected for Aecidium garckeanum and spermogonia are reported for this rust for the first time. The rust fungi of Ehrharta (Poaceae) are discussed and critically evaluated in the light of spore morphology and host species.

\section{Keywords Combretum $\cdot$ Dietelia $\cdot$ Ehrharta .} Endophyllum $\cdot$ Ziziphus

\section{Introduction}

Today, we know of some 530 species of rust fungi (Uredinales/Pucciniales) from South Africa (Berndt 2008a, and unpublished results). The bulk of them were recorded or described by E.M. Doidge who enumerated 474 species in her checklist of South African fungi and lichens (Doidge 1950). A total of 49 of these recorded taxa have been recognized meanwhile to represent anamorph states or synonyms of already known species (Crous et al. 2006). Thus, about 110 species were added to the South African rust mycobiota during the last 60 years, many of them only recently (e.g., Berndt 2008b, 2010; Berndt and Uhlmann 2006; Mennicken and Oberwinkler 2004; Wood 2006, 2007) indicating that South Africa remains under-collected. An important aspect is that many of the described species have been collected only once or a few times and are therefore incompletely known with regard to morphological characters and variability, host range and geographical distribution.

The present paper adds novel information on both mentioned aspects. It describes three species as new to science, 
reports four known rust fungi as new for South Africa and contributes a number of observations on the life cycle, host range and morphology of already known rust species.

\section{Materials and methods}

The investigated rust species are dealt with by host families which are arranged alphabetically. The studied specimens are listed under the respective rust species.

Spores and hand sections obtained from herbarium material were mounted in lactophenol or lactic acid and gently heated to facilitate soaking of the fungal structures and host tissue. Urediniospores of Sphaerophragmium dalbergiae Dietel and Phakopsora stratosa (Cooke) Arth. were stained according to the method of Jennings et al. (1989). Spores of Aecidium spp. were germinated on water agar $(1.5 \%)$ in 6-cm-diameter Petri dishes at room temperature, or incubated at 15 and $20^{\circ} \mathrm{C}$ and checked after 24 or $48 \mathrm{~h}$ with a microscope for basidium formation. Slides were examined with an Olympus BX51 compound microscope equipped with a ColorView IIIu camera. The Cell ${ }^{\wedge} \mathrm{B}$ software package (Software Imaging System) was used to capture micrographs and to measure details of spore walls and their ornament. Such measurements are given to $0.1 \mu \mathrm{m}$ while measurements made by the use of an ocular micrometer scale are given to $0.5 \mu \mathrm{m}$. Normally, $40-50$, but at least 30 spores were measured for each spore state. If, occasionally, fewer spores were studied this is indicated in the text. The arithmetic means are given in parentheses. Names of herbaria are abbreviated by their acronyms according to Index Herbariorum (Holmgren et al. 1990). HeRB stands for the first author's herbarium located at ZT, RSA numbers are field numbers of collections made by the first author. Spore states are designated according to the ontogenic terminology (Hiratsuka 1973). For brevity, the spore states present in herbarium specimens were indicated by the Roman numerals, I for aecia, II for uredinia, III for telia (or the respective spores) and by 0 for spermogonia. It should be noted that the application of these numerals to states of the life cycle is in contrast to their original use for morphological types of sori.

\section{Results and discussion}

Asteraceae

Endophyllum metalasiae (Syd. \& P. Syd.) A. R. Wood \& R. Berndt, comb. nov. (Fig. 1)

Basionym: Aecidium metalasiae Syd. \& P. Syd., Annls. Mycol. 10: 35 (1912). Type on Metalasia muricata R. Br. [probably M. densa (Lam.) P. O. Karis, fide Wood and Crous (2005)], Pole-Evans no. 686.

Material examined: South Africa: Western Cape: Cedarberg, along R303 between Citrusdal and Ceres, $32^{\circ} 37^{\prime} \mathrm{S} 19^{\circ} 9^{\prime} \mathrm{E}$, on Metalasia dregeana DC., leg. AR Wood no. 778, 3 Aug 2010 (PREM III); Cedarberg, along R303 between Citrusdal and Ceres, $32^{\circ} 37^{\prime} \mathrm{S} 19^{\circ} 7^{\prime} \mathrm{E}$, on Metalasia albescens Karis, leg. AR Wood no. 779, 3 Aug 2010 (PREM III).

Aecidium metalasiae was considered to be likely one of a complex of Endophyllum species (Wood and Crous 2005), but aecidiospores have not so far been germinated. Recently, fresh specimens were collected, and the spores germinated at 15 and $20^{\circ} \mathrm{C}$. At both temperatures, two septa were produced in each basidium (5-6 $\mu \mathrm{m}$ in width), and the two distal cells each germinated to form a further germ tube (Fig. 1). This confirms that this species should be transferred to Endophyllum, and also distinguishes it from the other species in this complex that produce two ( $E$. osteospermi (Doidge) A.R. Wood, E. dimorphothecae A.R. Wood \& Crous) or four (E. elytropappi A.R. Wood \& Crous) modified vesicle-like basidiospores (Wood and Crous 2005).

\section{Combretaceae}

Phakopsora combretorum A. R. Wood \& R. Berndt, spec. nov. (Fig. 2)

Anamorph: Uredo combreticola Doidge. Bothalia 3:506 (1939).

Etymology: Occurring on Combretum species.

Spermogonia et aecia ignota. Uredinia amphigena plerumque magis numerosa in pagina abaxiali - dense vel laxe sparsa vel in gregibus parvis disposita, minuta subepidermalia cupulata, peridio unistratoso (typi Milesiae) et nonnunquam paraphysibus clavatis simplicibus tenue tunicatis hymenii praedita; copia sporarum cinnamomea; urediniosporae obovoideae 19-25×14-18.5 $\mu \mathrm{m}(21.5 \times$ $16.1 \mu \mathrm{m}$ ), pariete ca. $1 \mu \mathrm{m}$ crasso pallide stramineo plus minusve regulariter echinulato spinis delicatis inter se ca. 1.5-2.5 $\mu \mathrm{m}$ distantibus, poris germinationis obscuris verosimiliter 4-5 plus minusve sparsa. Telia in foliis abaxialia vel adaxialia sparsa parva subplana ceracea pallide brunnea vel straminea semper urediniis arcte consociata; teliosporae dense et irregulariter aggregatae 3-5 superpositae, in sectione rectangulares subrhombicae vel cuneatae $12.5-27 \times 6.5-10 \mu \mathrm{m}(18.7 \times 8.2 \mu \mathrm{m})$, pariete levi vix $1 \mu \mathrm{m}$ crasso subhyalino vel pallidissime aureo in teliosporis exterioribus, poro germinationis apicali lentifomi; germinatio sporarum non visa ut videtur post quiescentiam. In foliis Combreti apiculati Sond. et Combretorum spp. 
Fig. 1 Germinating teliospores of Endophyllum metalasiae and basidia (AR Wood no. 779). Bars $100 \mu \mathrm{m}$ (upper one for upper row, lower one for lower row)

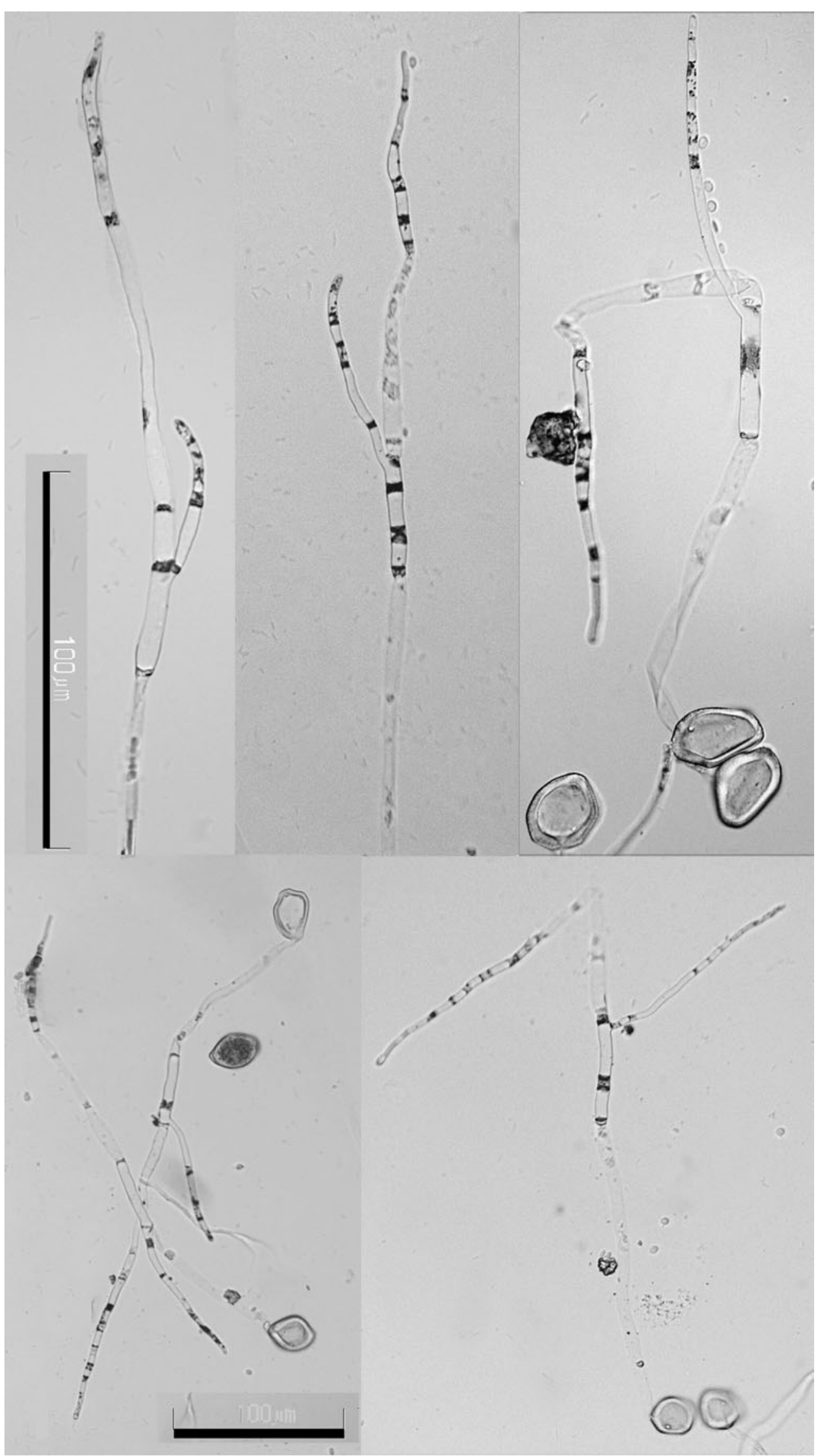




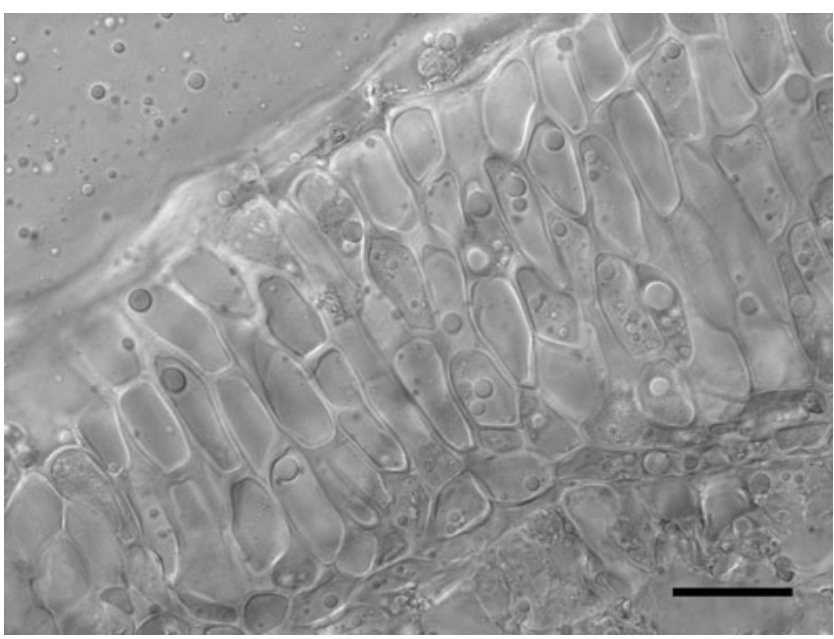

Fig. 2 Phakopsora combretorum (isotype), subepidermal telium composed of pale, superimposed teliospores. Bar $20 \mu \mathrm{m}$

Spermogonia and aecia unknown. Uredinia amphigenous on leaves, usually more numerous on abaxial surface, densely to loosely scattered or in small groups, tiny, subepidermal, dome-shaped, provided with a one-layered peridium (Milesia-type) and - sometimes - clavate, thinwalled, simple, hymenial paraphyses, spore mass cinnamon; urediniospores obovoid, 19-25×14-18.5 $\mu \mathrm{m}(21.5 \times$ $16.1 \mu \mathrm{m})$, spore wall about $1 \mu \mathrm{m}$ thick, pale straw-colored, more or less evenly covered by fine spines that are ca. 1.5$2.5 \mu \mathrm{m}$ apart, germ pores obscure, probably 4-5 more or less scattered. Telia abaxial on leaves (always?) as small, flat, wax-like, pale brownish crusts, scattered or often closely associated with uredinia, composed of 3-5 superimposed layers of teliospores; teliospores in section rectangular, rhomboid or wedge-shaped, 12.5-27 $\times 6.5-$ $10 \mu \mathrm{m}(18.7 \times 8.2 \mu \mathrm{m})$, spore wall smooth, hardly $1 \mu \mathrm{m}$ thick, subhyaline or very pallid golden in uppermost spore layer, with an indistinct, apical lens-shaped germ pore; germination not observed, apparently after resting period. On leaves of Combretum apiculatum Sond. and Combretum spp.

South Africa, Mpumalanga: S of Penge, near entrance to Serowe gorge, $24^{\circ} 25^{\prime} \mathrm{S} 30^{\circ} 26^{\prime} \mathrm{E}$, on C. apiculatum, leg. AR Wood no. 734, 27 Jul 2008 (PREM 60081, holotype. ZT Myc 951, isotype. II, III).

Additional material studied: South Africa, KwaZuluNatal: Silverglen Nature Reserve, Chatsworth, Durban, on Combretum zeyheri Sond., leg AR Wood no. 714, 27 May 2008 (PREM 60118. II). Durban, Queensburgh, Roosfontein Nature Reserve, on C. molle R. Br. ex G. Don, leg. AR Wood no. 752, 15 Jun 2009 (ZT Myc 2597. II, III). Mpumalanga: S of Penge, near entrance to Serowe gorge, $24^{\circ} 25^{\prime} \mathrm{S} 30^{\circ} 26^{\prime} \mathrm{E}$, on Combretum hereroense Schinz, leg. AR Wood no. 735, 27 Jul 2008 (PREM 60132. II).
The present rust has been reported before as Uredo combreticola from South Africa on C. zeyheri Sond. (Doidge 1939) and from Namibia on C. cf. engleri Schinz and C. hereroense Schinz (Mennicken et al. 2005). Combretum apiculatum appears to be a new host. The only other Phakopsora species described on Combretaceae is $P$. chavesii Dianese, Santos \& Medeiros on Terminalia in Brazil. The morphology of that species is unclear. According to the Latin description (Dianese et al. 1993) it has 2-3 layers of teliospores and uredinia lacking a peridium but with hymenial paraphyses. In the English description, 2-4 layers of teliospores are described and uredinia without paraphyses but with a hyphal peridium. $P$. chavesii differs from the present species in thicker-walled fulvous teliospores. Cerotelium combreti Cumm. from West Africa and Uganda has uredinia with dorsally and apically thick-walled peripheral paraphyses (Cummins 1952; Viennot-Bourgin 1958). According to the description given by ViennotBourgin (1959) the telia resemble those of the present species quite closely but the urediniospores are smaller and have equatorial germ pores.

\section{Cyperaceae}

Puccinia cf. scirpi DC. Fl. Fr. II: 223 (1805) on Ficinia spp. from the Western Cape (Fig. 3)

Material examined: On Ficinia spp. - South Africa, Western Cape: Kleinmond, Kogelberg Nature Reserve, in Oudebos River valley, on $F$. cf. trichodes, leg. E. Uhlmann \& R. Berndt no. RSA 426, 4 Nov 2005 (PREM no. to be assigned, ZT Myc 3304. II, III). Cederberge, road 303 from Citrusdal to Ceres, Middelberg Pass, 32 37'18”S $19^{\circ}$ 07'58'E, on F. cf. levynsiae Arnold \& Gordon-Gray, leg. E. Uhlmann \& R. Berndt no. RSA 44, 22 Oct 2004. (PREM, ZT Myc 3305. II).

On Scirpus lacustris L. - France, Departement de l'Ain: Pond near Dompierre-en-Dombes, leg. E. Mayor s. n., 30 Aug 1937 (ZT Myc 2789. II, III). Germany, Bavaria: Ingolstadt, leg. E. Eichhorn s. n., 20 Sep 1932 (ZT Myc 2788. II, III). Hungary: locality illegible, leg. F. Greinich, 16 Sep 1926 (ZT Myc 2787. II, III).

Puccinia austrina McKenzie. - New Zealand: Campbell Island, Mt. Honey, on Isolepis habra (Edgar) Soják, leg EHC McKenzie no. EHC 116, 7 Mar 2000 (PDD 87917, holotype. II).

Ficinia is a genus of about 60 species that are, with a few exceptions, confined to the Cape Floristic Region (Goldblatt and Manning 2000). It is closely related to Isolepis and both are currently included in tribe Cypereae of Cyperaceae (Muasya et al. 2009). Two Puccinia spp are known on members of Ficinia: Puccinia austrina on $F$. nodosa (Rottb.) Goetgh. (= Scirpus nodosus Rottb.) in 


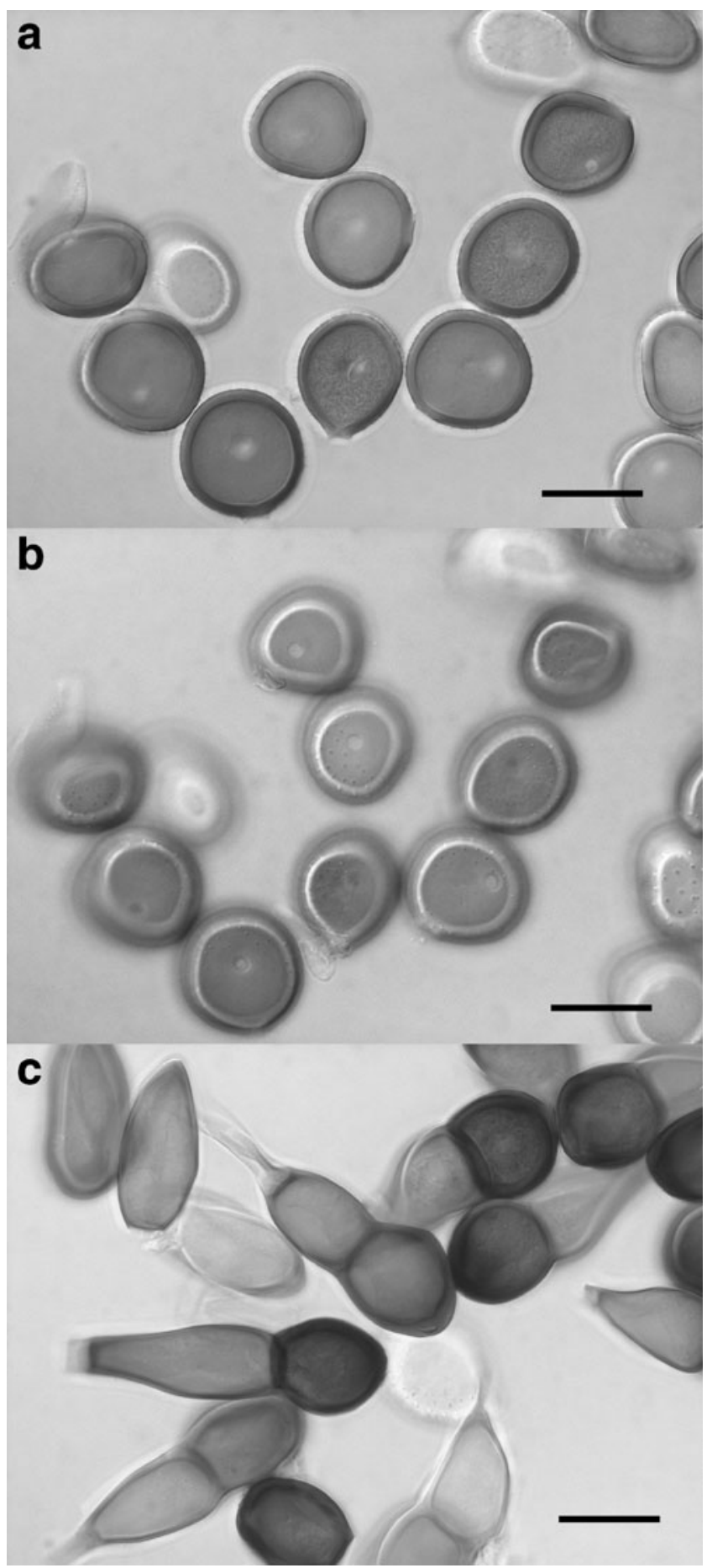

Fig. 3 Puccinia aff. scirpi (ZT Myc 3304). a Urediniospores, optical section. b Urediniospores, focus on spore surface. Note large bald patch proximal to germ pores. c Teliospores. Bars $20 \mu \mathrm{m}$

Australia (McAlpine 1906, sub Uredo scirpi-nodosi McAlp.) and P. conclusa Thüm. on F. 'capitaltum' Nees (probably F. capitellum Nees is meant) in South Africa (Jørstad 1956). A Puccinia collected on Ficinia in the Fynbos vegetation of Western Cape Province could not be assigned to the latter rust species, differing in non-locular, early naked telia, teliospores with a thinner apex and possibly by bald patches on the surface of the urediniospores (e.g., Gäumann 1959; Mayor and Terrier 1957). It should be mentioned that Barreto and Evans (1995) synonymized $P$. conclusa with $P$. canaliculata Schw. ex Lagerh. and presented a SEM micrograph of a urediniospore of the type of $P$. canaliculata that may show an indistinct tonsure proximal to the germ pore. It is uncertain whether the single shown spore is representative for the species. The present rust was very similar to $P$. austrina in urediniospore characters (Fig. 3a, b) but had longer, more darkly pigmented teliospores (Fig. 3c). P. isolepidis Gjærum from Ethiopia and Uganda is the only other known species on Isolepis (Gjærum 1990a). The specimens on Ficinia are also similar to that species but have a thicker urediniospore wall and a less thickened teliospore apex. They also differed from U. scirpi-corymbosi Doidge and $U$. scirpi-maritimi Doidge described from South Africa on Scirpus spp. (Doidge 1939, 1941) and were preliminarily assigned to $P$. scirpi, which has very similar uredinio- and teliospores. We noticed only small differences in the urediniospores which have a thicker spore wall (Fig. 3a) and a smooth patch located proximal to the germ pores on Ficinia (Fig. 3b). In P. scirpi, bald patches are present as well — though sometimes indistinct—but they are placed over and around the germ pores more or less symmetrically. The presence of smooth patches in urediniospores of $P$. scirpi has not been reported hitherto (e.g., Klebahn 1914; Gäumann 1959; Zhuang 1988). P. scirpi is heteroecious and infects members of Menyanthaceae in its haplontic stage (Aecidium nymphoidis DC.). Nymphoides indica (L.) Kuntze, a host of $A$. nymphoidis DC. in Uganda (Gjærum et al. 2003), also occurs in the Cape region (Goldblatt and Manning 2000) and might serve as the alternate host. P. scirpi would be a new member of the South African rust fungi.

The following description is based on the investigated specimens on Ficinia: Spermogonia and aecia unknown. Uredinia on abaxial side of leaves on straw-colored to brown leaf spots, subepidermal, shortly elliptic or longitudinally elongated, surrounded by the torn epidermis, ferrugineous and pulverulent. Urediniospores obovoid, subglobose to transversely broadly ellipsoid, generally slightly compressed along axis between the 2 opposite, equatorial to superequatorial germ pores, $21-31 \times 17.5-24.5 \mu \mathrm{m}(25.3 \times$ $21.0 \mu \mathrm{m}$ ), wall ca. $1.5-2 \mu \mathrm{m}$ thick, golden to orange brown, finely and rather distantly echinulate except for two conspicuous bald patches proximal to the germ pores. Telia as uredinia, but blackish brown to black, subcompact and early naked. Teliospores subclavate to subpyriform, more rarely ellipsoid, sometimes slightly deformed, at the septum hardly or slightly constricted, occasionally pronouncedly constricted, distal cell \pm round, rounded at the apex, about as 


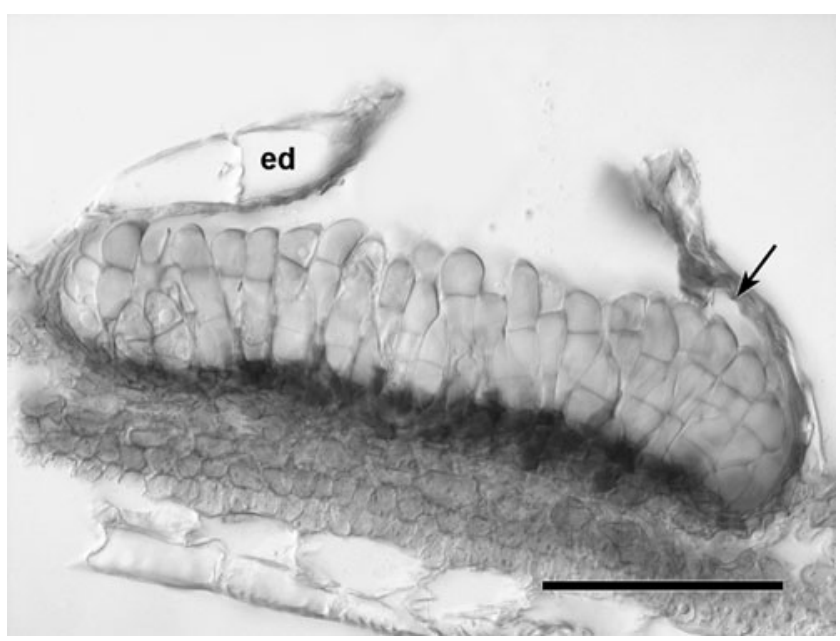

Fig. 4 Puccinia subcoronata (ZT Myc 2786), section through telium showing subepidermal position ( $e d$ epidermis) and the presence of a thin hyphal peridium (arrow) attached to the epidermis. Bar $100 \mu \mathrm{m}$

long as the conical proximal cell which is tapering towards the subhyaline to light brown and slightly thick-walled pedicel, $33-65 \times 15.5-23.5 \mu \mathrm{m}(47.3 \times 19.3 \mu \mathrm{m})$, wall smooth, light to dark chestnut brown and 1-2 $\mu \mathrm{m}$ thick in distal cell with apex to 2-5(6) $\mu \mathrm{m}$ thick, in proximal cell pallid brown to light chestnut and about $1 \mu \mathrm{m}$ thick; germ pores indistinct, apical in distal cell, probably close to the septum in the proximal cell; one-celled spores few to numerous.

Puccinia subcoronata Henn. Hedwigia 34:94 (1895), a new record for South Africa and the Old World on a new host plant (Fig. 4)

Syn.: Puccinia antioquiensis Mayor. Mém. Soc. Neuch. Sci. Nat. 5: 473 (1913) (fide Jackson 1926).

Material examined: South Africa, KwaZulu-Natal: Durban, Westville, Roosfontein Nature Reserve, on Cyperus albostriatus Schrad., leg. AR Wood no. 705, 27 Dec 2006 (ZT Myc 3302. II, III) and no. 753, 15 Jun 2009 (PREM 59915, ZT Myc 2786. II, III). Brazil: Goyaz, near Goyaz, on Cyperus diffusus Vahl, leg. E. Ule no. 1985, Feb 1893 (HBG, holotype. II, [III]).

Puccinia collected on Cyperus in Natal could not be identified as any of the Puccinia species reported to date on Cyperus in Africa [P. canaliculata, P. conclusa, P. cyperi Arth., P. cyperi-cristati Gjærum, P. cyperi-fastigiati Doidge, $P$. cyperi-tegetiformis Kern, $P$. flavo-virens Jacks., $P$. morganae Doidge, $P$. morotoensis Gjærum, $P$. pegleriana Doidge, P. philippinensis Syd. \& P. Syd., P. pottsii Doidge, P. romagnoliana Maire \& Sacc., P. transvaalensis Doidge] (e.g. Doidge 1927; Gjærum 1984). It had some resemblance to the widespread $P$. canaliculata though it differed in shorter teliospores (28-56 vs. 39-64 $\mu \mathrm{m})$ with a less thickened spore apex $(2.5-5(6)$ vs. $3-10 \mu \mathrm{m})$ and a more weakly pigmented spore wall (Barreto and Evans 1995; Kern 1919; Zhuang 1988). It should be noted that Barreto and Evans (1995) synonymize $P$. canaliculata with $P$. conclusa, P. philippinensis and P. romagnoliana.

The species which it resembled most was $P$. subcoronata. This rust is characterized by thin-walled uredinio- and teliospores and an only slightly thickened teliospore apex (Mayor 1914; Kern 1919). The South African specimen tallied well with all characters of $P$. subcoronata. However, we observed the presence of a few one-celled mesospores and that telia were immersed in a chestnut brown stromatic hyphal mass (Fig. 3), characters that have not been described for $P$. subcoronata. In the type of $P$. subcoronata, only two tiny telia were discovered of which one was sectioned. It was bounded by a palisade-like sterile hyphal layer and contained a single one-celled spore among two-celled teliospores. The present specimen is therefore assigned to P. subcoronata. This is the first report of this rust fungus outside of the New World on a new host species.

Uromyces cypericola Gjoerum. Lidia 3: 22 (1990), new for South Africa, with a description of the urediniospores (Fig. 5)

Material examined: South Africa, KwaZulu-Natal: Scottborough, Roberts Nature Reserve, on Cyperus albostriatus Schrad., leg. AR Wood no. 706, 5 Jun 2006 (PREM 59913. ZT Myc 3303. (II), III).

A rust fungus collected on Cyperus in KwaZulu-Natal was identified as $U$. cypericola hitherto only known from the type specimen from Kenya on Cyperus cyperoides Kük. ssp. pseudoflavus (Kük.) Lye (Gjærum 1990b). It had shorter teliospores than the type of $U$. cypericola $[22-31(35) \times 13-$ $20 \mu \mathrm{m}(25.9 \times 16.5 \mu \mathrm{m})$ vs. $27-40 \times 15-19 \mu \mathrm{m}]$ and bore urediniospores (Fig. 5) so far unknown in U. cypericola:

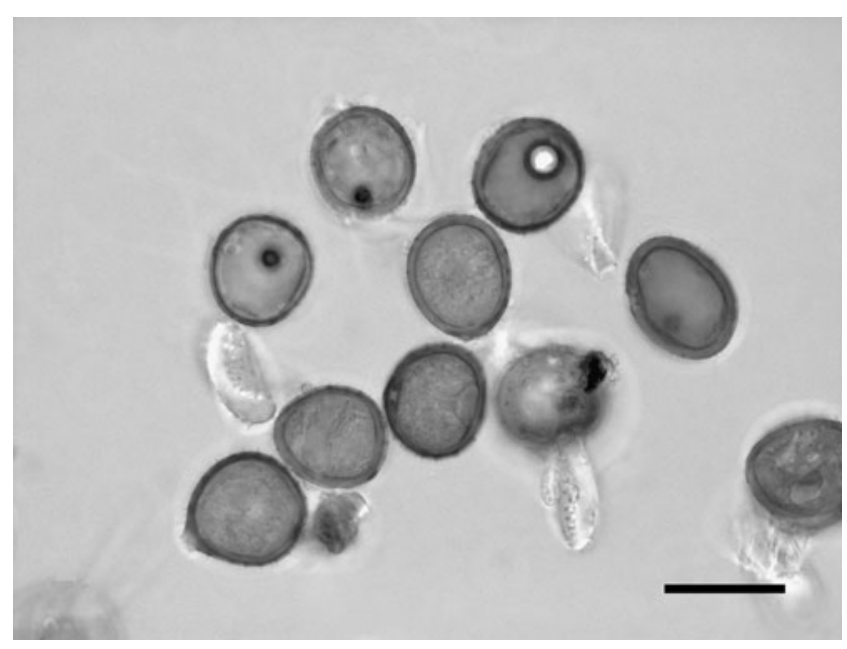

Fig. 5 Uromyces cypericola (ZT Myc 3303), urediniospores. Bar $20 \mu \mathrm{m}$ 
Uredinia not observed; urediniospores scattered on the surface of telia, obovoid to subglobose, wall light orange brown, ca. 1.5(-2) $\mu \mathrm{m}$ thick, more or less evenly echinulate with spines ca. $2-3 \mu \mathrm{m}$ apart and $0.5-1 \mu \mathrm{m}$ long, germ pores 2 , more or less opposite, equatorial or super-equatorial, with or without(?) a bald patch proximal to the pores.

Other Uromyces spp. known on Cyperus, namely $U$. bermudianus Cummins, U. cyperi Henn., U. cyperinus Speg. and $U$. notabilis Wakef., did not tally with the characters of the present specimen. This is the second collection of $U$. cypericola, a new report for South Africa and a new host species.

\section{Euphorbiaceae}

Crossopsora antidesmae-dioicae (Syd. \& P. Syd.) Arth. \& Cummins. Philipp. J. Sci., C, Bot. 61: 474 (1937), first report from South Africa

Material examined: South Africa, KwaZulu-Natal: Uvongo, Skyline Nature Reserve, on Antidesma venosum E. Mey. ex Tul., leg. AR Wood no. 720, 29 May 2008 (PREM 60114, ZT Myc 579. II).

Crossopsora antidesmae-dioicae has been reported on the same host species as the South African specimen from Ivory Coast (Viennot-Bourgin 1958) and Uganda (Cummins 1945). It is otherwise known from China, Indonesia, Japan, New Guinea, the Philippines and Vietnam. The known localities indicate that $C$. antidesmae-dioicae is widely distributed in warm regions of the Old World.

\section{Phakopsora stratosa (Cooke) Arth. Bull. Torrey Bot. Club 44: 508 (1917), first report of spermogonia and aecia and observations on the morphology of the uredinia and urediniospores (Fig. 6)}

Material examined: South Africa, KwaZulu-Natal: Durban, Yellowwood Park, Kenneth Stainbank Nature Reserve, on Croton sylvaticus Hochst., leg. AR Wood no. 698, 14 Dec 2006 (PREM 60109, ZT Myc 581. 0, I, II, III); Inanda, on C. sylvaticus, leg. JM Wood no. 466, 12 Jan 1881 (PREM 10363, Isotype. II); Winkle Spruit, on C. sylvaticus, leg. IB PoleEvans s. n., 14 Feb 1913 (PREM 5639, II); Eshowe, on C. sylvaticus, leg. APD McClean s. n., Apr 1941 (PREM 33093, II, III).

Phakopsora stratosa has been recorded previously from South Africa on C. sylvaticus (Sydow and Sydow 1915; Wood 2006) and from Ethiopia on C. macrostachys (Castellani and Ciferri 1950). An investigation of recently collected material revealed the presence of spermogonia and aecia that have not been observed hitherto and some morphological characters that supplement existing descriptions (Doidge 1927; Sydow and Sydow 1915):

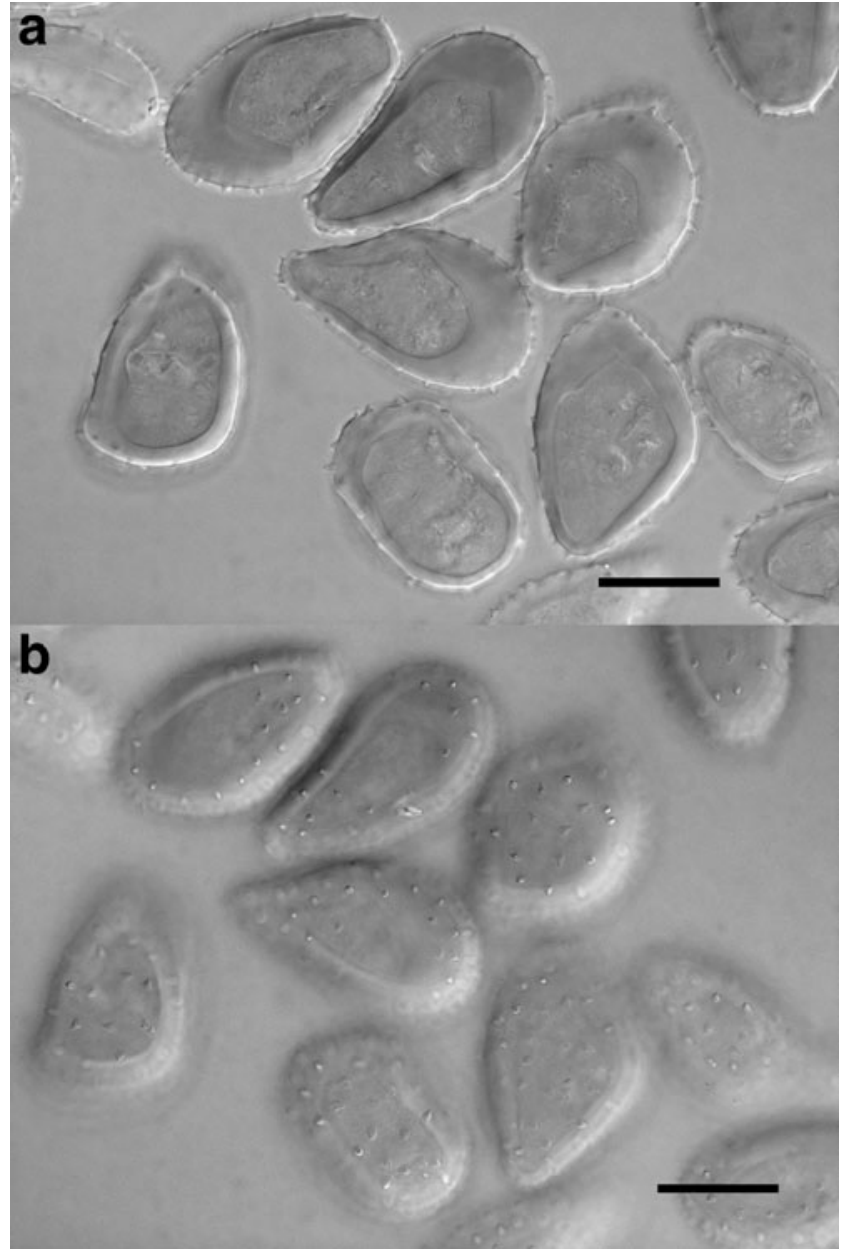

Fig. 6 Phakopsora stratosa (ZT Myc 581), urediniospores. a Optical section. b Focus on spore surface. Note lateral patch lacking echinulation. Bar $20 \mu \mathrm{m}$

Spermogonia subcuticular with flat hymenium, type 7 , 120-200(-250) $\mu \mathrm{m}$ diam., amphigenous on leaves, in dense groups on large, round, brown spots that become necrotic with age, or on small gall-like swellings of branchlets and leaf petioles; groups of spermogonia surrounded by old and mostly empty aecia. Aecia Uredolike. The few aeciospores present were pedicellate and identical with the urediniospores. Uredinia amphigenous on leaves, scattered or in small groups, pustulate with a peridium adhering to the overarching host epidermis (Milesia-type), pulverulent, cinnamon brown; urediniospores (Fig. 6) pedicellate, narrowly obovoid to subclavate, slightly asymmetrical with a ventral, slightly flattened side and a dorsal, more convex side, spore wall pale golden brown, indistinctly bi-layered, the inner layer being more deeply pigmented, ca. 3-4 $\mu \mathrm{m}$ thick at sides around the two, more or less equatorial and opposite germ pores, up to $10 \mu \mathrm{m}$ thick at apex, echinulate by rather coarse spines which are ca. 4-6 $\mu \mathrm{m}$ apart - except for a smooth patch on the ventral side of the spore. 
Both Sydow and Sydow (1915) and Doidge (1927) described urediniospores with four germ pores and did not mention the asymmetry of the spores and the presence of a smooth ventral patch. However, after staining, only two pores were observed in all specimens studied by us including an isotype (PREM 10363). The occurrence of spermogonia and aecia together with uredinia and telia prove that $P$. stratosa is a macrocyclic autoecious rust species. Unfortunately, the aecia were old and mostly parasitized by a Tuberculina species, so that a full description cannot be given.

Fabaceae

Sphaerophragmium dalbergiae Dietel. Hedwigia 32: 30 (1893), a revised description of the urediniospores

Material examined: South Africa, KwaZulu-Natal: Umkomaas, Empisini Nature Reserve, on Dalbergia armata E. Mey., leg. AR Wood no. 709, 6 Jun 2007 (PREM 59914. II); Durban, on D. armata, leg. IB PoleEvans s. n., 13 Apr 1911 (PREM 1371, II); Durban, Umgeni beach, on $D$. armata, leg. EM Doidge s. n., 7 Jul 1912 (PREM 2524. II).

Lohsomboon et al. (1994) stated that the number of germ pores of the urediniospores of $S$. dalbergiae could hardly be discerned and gave it as 1-2 in accordance with the descriptions provided by Monoson (1974, one pore) and Dietel (1893, two pores). Viennot-Bourgin (1958) counted four pores in an equatorial position. After staining the spores, germ pores were more easily visible and 4-7 pores were observed most often in an approx. equatorial position, more rarely tending to be scattered. Our urediniospore measurements of $23-34 \times 13-15.5 \mu \mathrm{m}(27.0 \times 14.2 \mu \mathrm{m}$, for 22 spores, PREM 59914) tallied quite well with the measurements published by Lohsomboon et al. (1994) in a specimen on $D$. armata from Natal $[21-34 \times 11-22 \mu \mathrm{m}$, $(27 \times 16.5 \mu \mathrm{m})]$, while Viennot-Bourgin $(1958)$ measured 20-31 $\times 15-25 \mu \mathrm{m}(26 \times 24.5 \mu \mathrm{m})$ in a specimen on Dalbergia sp. from the Ivory Coast. The second mean value may be an error. The uredinial paraphyses observed in our specimen agreed well with the description and illustration published by Viennot-Bourgin (1958).

Malvaceae

Endophyllum mpenjatiense A. R. Wood \& R. Berndt, spec. nov. (Fig. 7)

Etymology: after the locus classicus, the Mpenjati Nature Reserve.

Differt ab Aecidiis spp. Hibiscorum spp. micromorphologia et germinatione sporarum basidiis.

In foliis Hibisci sp. verosimiliter.
Telia Aecidium-like, mainly on abaxial side of leaves, in dense groups on bleached leaf spots, telia cup-shaped, 150 $290 \mu \mathrm{m}$ diam., short, with peripheral peridium whose margin is frayed or lacerating into a few lobes, peridial cells only weakly adherent and easily separating, irregularly shaped but generally more or less rectangular, outer periclinal wall ca. $6 \mu \mathrm{m}$ thick, finely and distantly verrucose, inner wall ca. 2-3 $\mu \mathrm{m}$ thick, more coarsely and very variably verrucose with irregular and rather distant warts; spore mass yellow when fresh, ebony or whitish in herbarium, subpulverulent, cottony-fibrous upon germination of basidia, teliospores subglobose, ellipsoid, broadly ellipsoid, often slightly deformed or subangular, 17-21.5× $12-16(18.8 \times 14.1 \mu \mathrm{m})$, spore wall $\leq 1 \mu \mathrm{m}$, very finely and densely verruculose with some interspersed bigger warts, becoming almost smooth or smooth at spore base, germinating in situ with basidia upon maturity, basidia $50-85 \times 6-10 \mu \mathrm{m}(n=8), 1$ or 2 septate, producing two thinwalled basidiospores on sterigmata; basidiospores ca. $10 \mu \mathrm{m}$ in diameter.

On leaves of cf. Hibiscus sp.

South Africa, KwaZulu-Natal: Mpenjati Nature Reserve between Ramsgate and Port Shepstone, on non-flowering Malvaceae plant, probably Hibiscus sp., leg. AR Wood no. 719, 28 May 2008 (holotype PREM 60113, isotype ZT Myc 583. III).

Additional material examined: Aecidium garckeanum Henn. Ethiopia (Abessinien, Colonia Eritrea): Unter Geleb, alt. 1,700 m, auf Hibiscus micranthus, leg. Schweinfurth $s$. n., 11 Apr 1891 (B 700014687: Lectotype, designated here. 0, I). Am Sabor Geleb, alt. 2,200 m, auf H. crassinervius, leg. Schweinfurth s. n., 20 Apr 1891 (B 700014688: Syntype. 0, I).

Aecidium garckeanum Henn. and A. hibisci-surattensis Mayor \& Vienn.-Bourg. are known on Hibiscus spp. in Africa, the former also from South Africa (Doidge 1927). Type material of $A$. garckeanum was compared with $E$. mpenjatiense and found to be different in characters of spores, peridium and life cycle. As Hennings (1891) did not designate a type specimen for A. garckeanum, one of the syntypes kept in Berlin, B 700014687, is selected here as lectotype. It showed spermogonia of group V / type 4 (classification acc. to Hiratsuka and Cummins 1963) that had not been described before. Marchal and Steyaert (1929) proposed Puccinia garckiana Marchal \& Steyaert to which they assigned $A$. garckeanum as the aecial anamorph. Sydow and Sydow (1924) suggested that A. garckeanum may be the same as A. erythrobasis Berk. \& Broome described from Sri Lanka but this species has larger spores (Gjærum 1985) and is also different from the present species. A. hibisci-surattensis Mayor \& Vienn.-Bourg. is very similar to $E$. mpenjatiense but has slightly larger spores and a peridium smooth on the outside; the spore 
Fig. 7 Endophyllum mpenjatiense. a Teliospores germinating with two-celled basidia (holotype, bars $10 \mu \mathrm{m})$. b Teliospores with finely verruculose surface. Arrows indicate spores where bigger warts are interspersed among minute ones. c Peridial cells: delicately verrucose outer periclinal wall ( $\mathrm{ar}$ row). d Peridial cells: irregularly verrucose inner periclinal wall (b-d, isotype, bars $20 \mu \mathrm{m}$ )

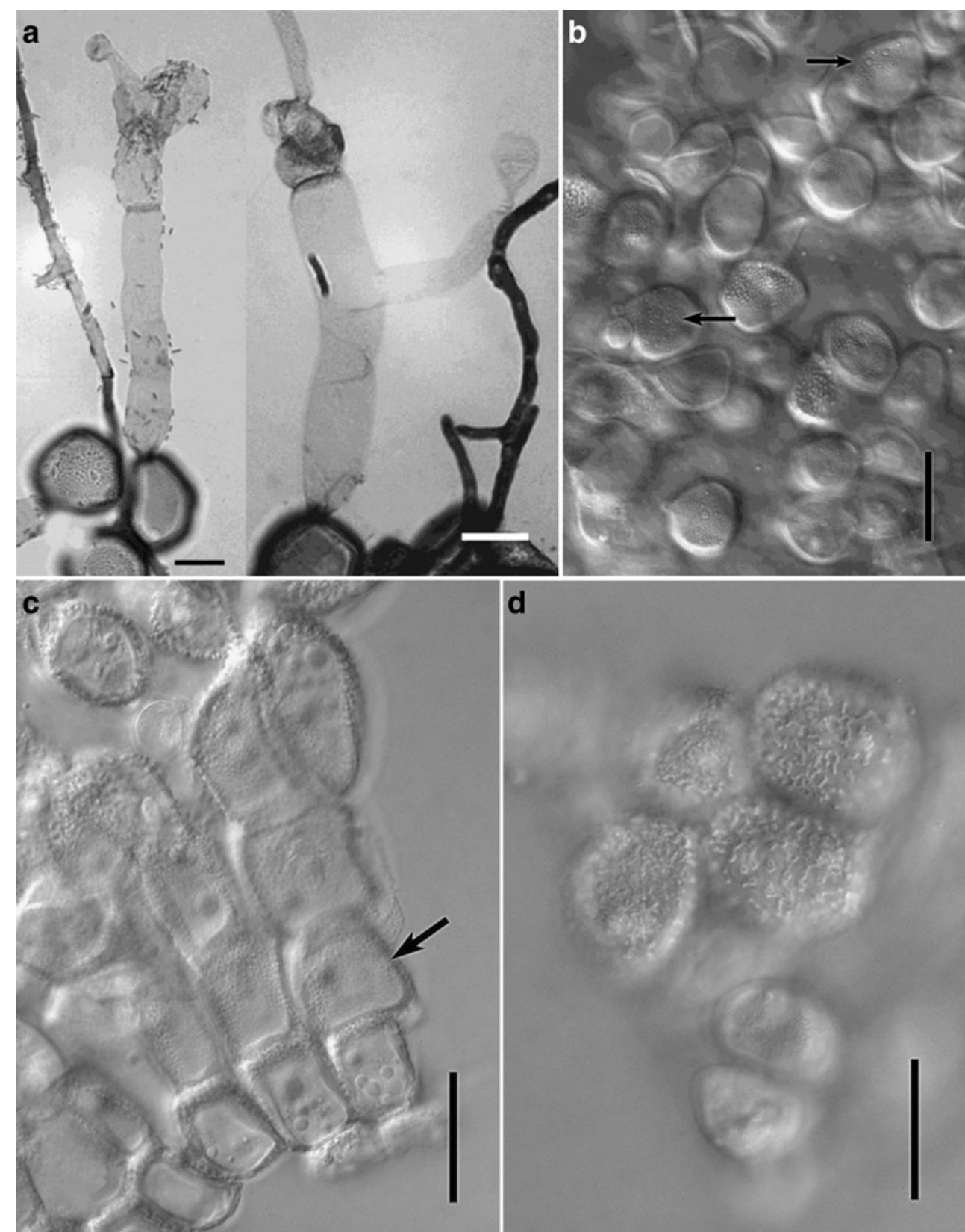

germination has not been recorded (Mayor and ViennotBourgin 1951).

\section{Poaceae}

\section{The rust fungi of Ehrharta (Ehrharteae)}

Material examined: Uromyces ehrhartae-giganteae: South Africa, Western Cape: Cape Town, Mowbray, on E. thunbergii Gibbs Russell (= E. gigantea Thunb.), leg. CP Van der Merwe, 10 Feb 1924 (PREM 7392, holotype. III. PUR F14562, isotype. III).

$U$. quaggafonteinus: South Africa, Northern Cape: Kamiesberg Mountains, along gravel road between
Kamieskroon and Leliefontein, on E. calycina J.E. Sm., leg. E. Uhlmann \& R. Berndt, 15 Oct 2004 (RSA 21. II, III). Kamiesberg Mountains, along gravel road from Kamieskroon to Soebatsfontein, on E. calycina, leg. E. Uhlmann \& R. Berndt, 15 Oct 2004 (RSA 23. II, III). Western Cape: Vanrhynsdorp, gravel road to Gifberg, on E. cf. calycina, leg. Rössel, Uhlmann \& Berndt, 12 Oct 2005 (RSA 186. II, III. Specimen probably represents a mixed infection as two kinds of urediniospores occur). Cederberge, Blinkbergpass, on E. calycina, leg. Rössel, Uhlmann \& Berndt, 17 Oct 2005 (RSA 240. (II), III. Specimen may represent a mixed infection as two kinds of urediniospores occur).

Uromyces indet.: South Africa, Northern Cape: Kamiesberg Mountains, on a granite koppie near Leliefontein, 
on Ehrharta barbinodis Nees ex Trin., leg. E. Uhlmann \& R. Berndt, 15 Oct 2004 (RSA 17. II, III). Along gravel road from Kamieskroon to Soebatsfontein, on $E$. cf. barbinodis, leg. E. Uhlmann \& R. Berndt, 17 Oct 2004 (RSA 24. II, III). Barrydale, on E. erecta Lam. var. erecta, leg. E. Uhlmann \& R. Berndt, 23 Oct 2004 (RSA 51. (II), III). Western Cape: Road from Clanwilliam to Pakhuis Pass, on Ehrharta sp., leg. Rössel, Uhlmann \& Berndt, 13 Oct 2005 (RSA 193. (II), III). Cederberge, at Pakhuis Pass, on E. cf. thunbergii, leg. Rössel, Uhlmann \& Berndt, 13 Oct 2005 (RSA 201. III). Cederberge, Uitkyk Pass, on E. cf. thunbergii, leg. Rössel \& Berndt, 15 Oct 2005 (RSA 235. (II), III).

Three rust fungi have been described on members of the genus Ehrharta in South Africa: Uromyces ehrhartaegiganteae Doidge, U. quaggafonteinus Mennicken \& Oberw., and Uredo ehrhartae-calycinae Doidge. Uromyces ehrhartae-giganteae is only known in the telial state whereas telio- and urediniospores were described for $U$. quaggafonteinus. Mennicken and Oberwinkler (2004) assigned Uredo ehrhartae-calycinae to $U$. ehrhartaegiganteae as its uredinial anamorph. This assumption can neither be verified nor falsified on grounds of morphology, as the type specimens of $U$. ehrhartae-giganteae kept in PREM and PUR do not contain any uredinia or urediniospores.

We collected two species of Uromyces bearing telio- and urediniospores on Ehrharta in the northern and western Cape Provinces. One of them was identified as U. quaggafonteinus, the other one could not be determined. It differed from $U$. quaggafonteinus in larger urediniospores and from $U$. ehrhartae-giganteae in the presence of a uredinial state. It is very probable that the uredinial state is identical with Uredo ehrhartae-calycinae as the urediniospores are most similar (Table 1). Uromyces quaggafonteinus and the undetermined species cannot be safely separated from $U$. ehrhartae-giganteae by teliospore characters. As urediniospores are unknown in $U$. ehrhartae-giganteae both species may be distinct from it or each of them may be the same as $U$. ehrhartae-giganteae.

The available collections indicate that $U$. quaggafonteinus may be restricted to E. calycina while the undetermined species appears to have a wider host range comprising $E$. barbinodis, E. calycina, E. erecta. var. erecta, E. cf. thunbergii and E. villosa. Uromyces ehrhartae-giganteae is presently only known from $E$. thunbergii (=E. gigantea).

\section{Rhamnaceae}

\section{Rust fungi of Ziziphus in southern Africa}

Two rust fungi, Crossopsora ziziphi (Syd. \& Butl.) Syd. \& P. Syd. and Phakopsora ziziphi-vulgaris Dietel, have been recorded from species of Ziziphus in Africa. A specimen recently collected on $Z$. mucronata Willd. was different from both of them and is described as new.

Uredo sekhukhunensis R. Berndt \& A. R. Wood, spec. nov. (Fig. 8) Syn. Cronartium ziziphi auct. Doidge EM 1948. Bothalia 4: 898. Non C. ziziphi Syd. \& Butl. 1912.

Etymology: denominating the Sekhukhunene region where the type specimen was collected.

Uredinia in gregibus parvis pagina abaxiali foliorum insidentia sparsa nonnihil confluentia subepidermalia pallide brunnea, annuliformiter corona ferruginea paraphysium circumdata, mature exposita pulverulentiaque; urediniosporae ellipsoideae subclavatae subpyriformes ad oblongae, $26-42 \times$ 14.5-20.5 $\mu \mathrm{m}(32.3 \times 17.2 \mu \mathrm{m})$, pariete $1-2 \mu \mathrm{m}$ crasso leniter tenuiore hilum versus stramineo vel pallide- ad aureobrunneo, echinulato spinis sate delicatis hilum versus decrescentibus, deinde levi, poris germinationis verosimiliter 4-6 approx. aequatorialibus papillis carentibus; paraphyses periphericae basaliter junctae (uredinia typi Physopellae) sine septis vel simplices septatae cylindricae ad subclavatae rectae vel leniter incurvatae saepe irregulariter distortae, pariete brunneo apicaliter et dorsaliter valde incrassato.

In foliis Ziziphi mucronatae Willd.

Uredinia scattered, but generally in small groups and slightly confluent on abaxial side of leaves, pale brown, with darker, ferrugineous border of paraphyses, subepidermal, early exposed and pulverulent; urediniospores ellipsoid, subclavate, subpyriform to oblong, 26-42×14.5$20.5 \mu \mathrm{m}(32.3 \times 17.2 \mu \mathrm{m})$, spore wall $1-2 \mu \mathrm{m}$ thick, slightly thinner towards hilum, straw-colored to pale or orange brown, echinulate by sharp and rather delicate spines which become finer towards the spore base and vanish on the proximal third of the spores, germ pores difficult to discern, probably 4-6, approx. equatorial to almost scattered, without caps; paraphyses peripheral and only basally united (uredinia of Physopella-type), without or with a single septum, cylindrical to subclavate, sometimes straight or slightly bent inwardly, generally distorted or gnarled or geniculate, cell wall brown, irregularly thickened, dorsally and apically often strongly so.

On leaves of Ziziphus mucronata Willd.

South Africa, Mpumalanga: S of Penge, track to Serowe gorge, $24^{\circ} 26^{\prime} \mathrm{S} 30^{\circ} 26^{\prime} \mathrm{E}$, on Z. mucronata, leg. AR Wood no. 733, 27 Jul 2008 (PREM 60080, holotype. ZT Myc 952, isotype. II).

Additional material investigated: on Z. mucronata. - South Africa, Limpopo: Between Acornhoek and Polokwane (Tzaneen), leg. LCC Liebenberg no. 3608, Jun 1939 (PREM 32724. II). D’Nyala Nature Reserve, Ellisras, leg. M. van Reenen no. 2/1, 28 Sep 1989 (PREM 50573. II). Mpumalanga: Burgersfort, leg. LCC Liebenberg no. 6215, May 1959 (PREM 41983. II). Lowveld Botanical Garden, Nelspruit, leg. M. van Reenen no. 5/11, 26 Apr 1990 (PREM 50576. II). Berg-en- 


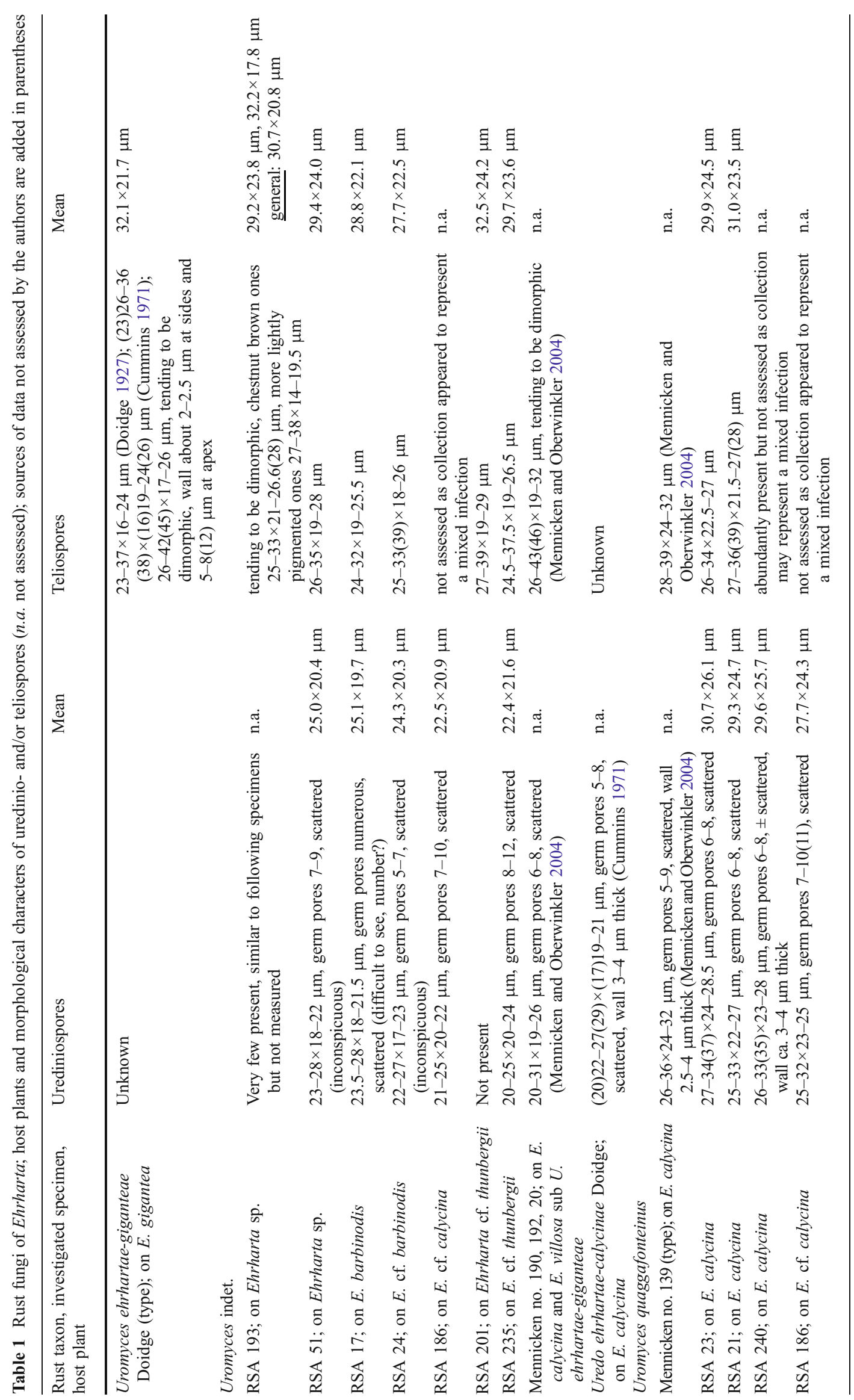



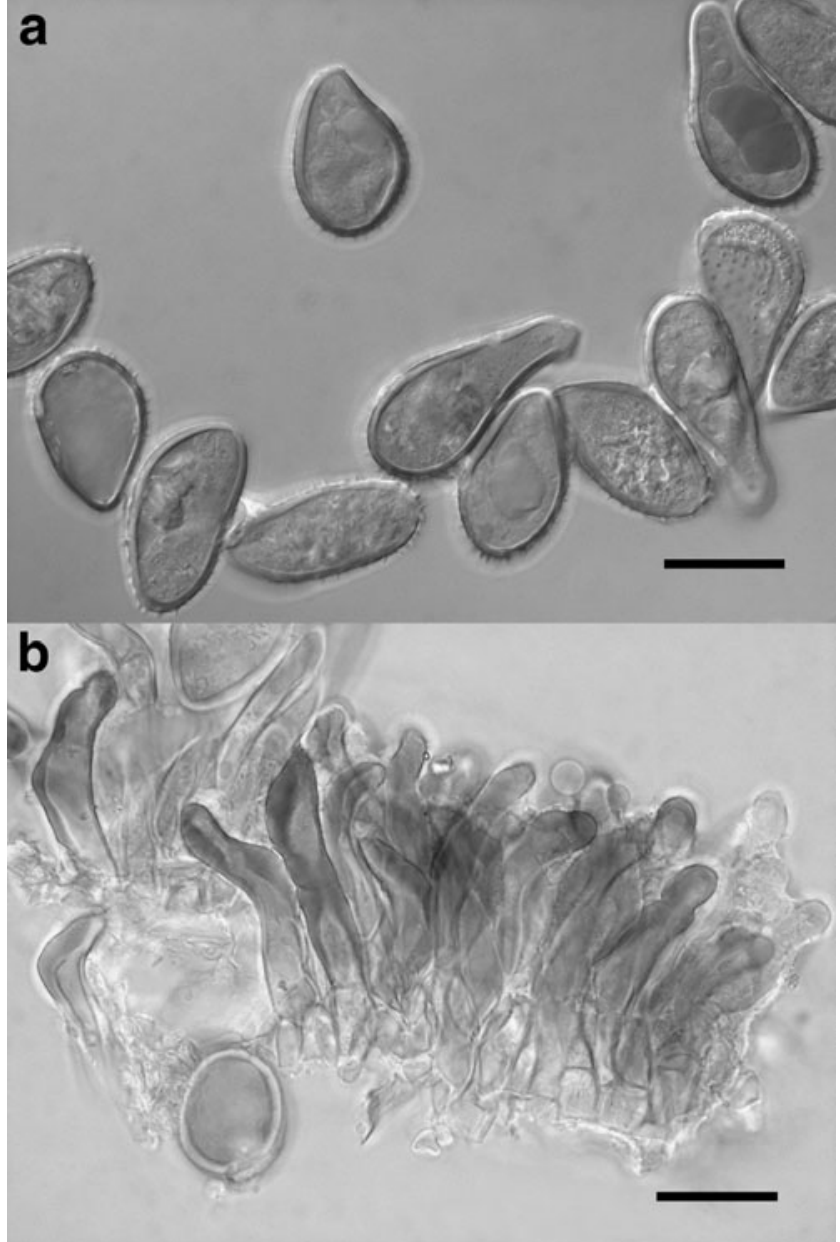

Fig. 8 Uredo sekhukhunensis (ZT Myc 952, isotype). a Urediniospores. b Uredinial paraphyses. Bars $20 \mu \mathrm{m}$

Dal, Kruger National Park, leg. M. van Reenen, 15 Jul 1991 (PREM 50696. II). Skukuza research camp, Kruger National Park, leg. AR Wood no. 646, 6 Apr 2006 (PREM 59108. II).

Crossopsora ziziphi (Syd. \& Butl.) Syd. \& P. Syd. Zambia: Gwembe Valley, on Z. abyssinica Hochst. ex A. Rich., leg. A. Angus, 17 Jun 1961 (PREM 43807, IMI 90070. II). Vietnam (as 'Tonkin'): Cho Gonh, on Ziziphus sp., leg. A. Petelot, Nov 1922 (Syd. Fungi exot. exsicc. no. 972, ZT Myc 1272, type. II, III). India, Goa State: between Honavar and Jog Falls, ca. $22 \mathrm{~km} \mathrm{E}$ of Honavar, on Ziziphus sp., leg. R. Berndt, 29 Oct 1995 (HeRB B-210. II). Karnataka State: on coastal road ca. $28 \mathrm{~km} \mathrm{~N}$ of Mangalore, on Ziziphus sp., leg. ND Sharma \& R. Berndt, 30 Oct 1995 (HeRB B-218. II, III).

Uredo sekhukhunensis (Fig. 9) differs from Crossopsora ziziphi that has shorter, slightly asymmetrical urediniospores with three more or less equatorial germ pores and uredinia with straight thin-walled paraphyses. Phakopsora ziziphi-vulgaris differs in smaller urediniospores and uredinia of Milesia-type; the uredinial stage of the Indian Kuehneola ziziphi (Ramakr.

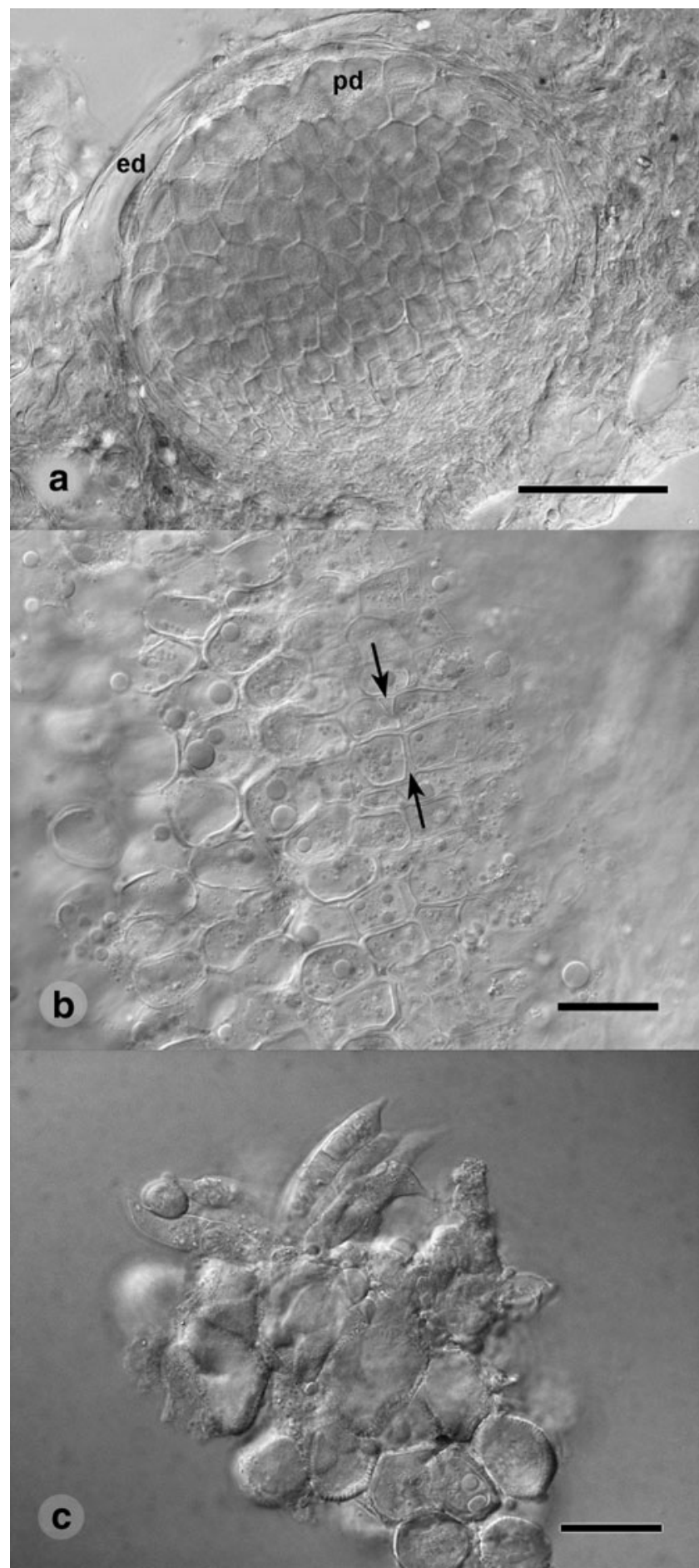

Fig. 9 Dietelia cardiospermi (ZT Myc 949). a Section through young telium still covered by host epidermis $(e d)$ and cellular peridium $(p d)$. bar $50 \mu \mathrm{m}$. b Section through telium showing teliospore chains with teliospores and intercalary cells (arrows). c Teliospores and basidia scraped from mature telium, partly hidden by debris. Bar $20 \mu \mathrm{m}$

\& Subram.) Thirum. in thick-walled and smaller urediniospores with scattered germ pores according to the description given by Ragunathan and Ramakrishnan (1973). 
In Africa, Crossopsora ziziphi has been recorded from Eritrea (sub Uredo zizyphi Pat., Castellani and Ciferri 1937), Zimbabwe (Whiteside 1966), and South Africa (Doidge 1948, sub Cronartium ziziphi). The description and illustration presented by Doidge (1948) indicate that not $C$. ziziphi but another rust species is involved in South Africa. Therefore, all South African specimens of C. ziziphi kept in PREM were examined and all those on $Z$. mucronata were found to represent the new species, $U$. sekhukhunensis. C. ziziphi has to be deleted from the lists of South African and Zimbabwean rust fungi.

Phakopsora ziziphi-vulgaris Dietel. Ann. Mycol. 8: 469 (1910), new for South Africa

Material examined: South Africa, Limpopo: Bela Bela (Warmbaths), Klein Kariba Resort, on Z. mucronata, leg. AR Wood no. 666, 23 May 2006 (PREM 60107, ZT Myc 580. II, III). India, Maharashtra State: Pune, Pune University campus, near the guesthouse, on $Z$. cf. jujuba Mill., leg. R. Berndt, 18 Nov 1995 (HeRB 4008. II/III). Bihar State: Pusa, on Z. jujuba, leg. EJ Butler, 5 Feb 1913 (Sydow, Fungi exot. exsicc. no. 165, ZT Myc 953 and Z $s$. n. II, III). Israel: Lidda, on Z. spina-christi Willd., leg. T. Rayss, 14 Nov 1951 (ZT Myc 962. II).

Phakopsora ziziphi-vulgaris is widely distributed in warm regions of the Old and New World. In Africa, it has only been recorded so far in Eritrea (Castellani and Ciferri 1937), in Uganda (Gjærum 1998) and from the Cape Verde Islands (Gjærum 1974). It was recently collected for the first time in South Africa on $Z$. mucronata with both uredinia and telia present. The South African specimen differed from other specimens by very finely echinulate or almost smooth urediniospores with slightly thicker spore walls; the remaining characters agreed well, however.

\section{Rosaceae}

Pucciniastrum agrimoniae (Dietel) Tranzschel. Scripta Bot. Horti Univ. Imper. Petrop. 4: 301 (1895), new host genera and species from South Africa

Doidge (1950) listed P. agrimoniae for South Africa on the indigenous Agrimonia bracteata E. Mey ex C.A. Mey. (sub A. eupatoria L. var. capensis Harv.). It is also recorded herein on Leucosidea sericea Eckl. \& Zeyh. and Cliffortia odorata L. To our knowledge, these are new host species and genera and the first records of $P$. agrimoniae on genera other than Agrimonia. All three genera belong to the same tribe, Sanguisorbeae of Rosoideae (Potter et al. 2007). $P$. agrimoniae shows a disjunct distribution between the northern and southern hemisphere, similar to some fern rusts of the Pucciniastraceae recorded from South Africa
(Berndt 2008a). Teliospores have not been observed in South Africa to our knowledge and the rust fungus may be able to persist in the uredinial state.

Material examined: on Leucosidea sericea. - South Africa, KwaZulu-Natal: Pietermaritzburg, Natal Botanical Garden, leg. AR Wood no. 135, 21 Jan 1999 (PREM 59039. II). Pietermaritzburg, Natal Botanical Garden, leg. AR Wood no. 561, 14 May 2004 (PREM 59040. II). Mpumalanga: Long Tom Nature Reserve, Long Tom Pass, NE of Lydenburg, leg. AR Wood no. 148, 12 May 1998 (PREM 59038. II). On Cliffortia odorata. - South Africa, Western Cape: Knysna, Knysna Forest, Lelievlei Nature Reserve, "Terblans Walk", leg. E. Uhlmann \& R. Berndt, 25 Oct 2004 (RSA 66. II). George, Outeniqua Nature Reserve, leg. AR Wood no. 379, 4 June 2002 (PREM 59042. II). Cape Town, Skeleton Gorge in Kirstenbosch Botanical Garden, leg. AR Wood no. 513, 17 March 2003 (PREM 59041. II).

\section{Sapindaceae}

Dietelia cardiospermi (Cooke) R. Berndt \& A. R. Wood, comb. nov. (Fig. 9)

Basionym: Aecidium cardiospermi Cooke. Grevillea 10: 125 (1882). Type on Cardiospermum microcarpum Kunth, Cooke no. 537

Material examined: South Africa, KwaZulu-Natal: Ngwavuma River about $1 \mathrm{~km} \mathrm{~S}$ of Ndumo village, on $C$. halicacabum L. var. halicacabum, leg. R. \& A. Urban, 15 Jul 2008 (PREM 60085, ZT Myc 949. III).

"Aecidium serjaniae" Henn. Brazil: São Paulo, Campinas, on leaves of Serjania sp., leg. F. Noack, 7 Nov 1896 (Sydow, Uredineen no. 2197, ZT Myc 2992. I). Venezuela, State Yaracui: between S. Pedro and Campo Elias (Panamericana highway between Barquisimeto and San Felipe), on cf. Serjania sp., leg. R. Berndt, 25 Nov 1993 (HeRB A-179, located at ZT. I).

Aecidium cardiospermi was described on the type host C. halicacabum L. var. microcarpum (Kunth.) Blume from KwaZulu-Natal and found on the same plant species in Zanzibar, Kenya (Sydow and Sydow 1903). We observed that the 'aeciospores' germinated in situ producing basidia and regard them as teliospores accordingly. Because of the firmly adherent teliospores (Fig. 9a, b) we transfer $A$. cardiospermi to Dietelia (Buriticá 1991; Buriticá and Hennen 1980) as D. cardiospermi. The formation and exact morphology of the basidia was difficult to assess as the peridial cells, basidia and compressed, empty teliospores formed a tangled mass on the mature sori. As far as observable, the basidia were two-celled and formed basidiospores on stout sterigmata (Fig. 9c). According to our knowledge $D$. cardiospermi has not been reported from 
outside of Africa. The host genus Cardiospermum is most speciose in the New World, but $C$. halicacabum is regarded as occurring naturally in South Africa by Arnold and de Wet (1993). A number of Aecidium species were described on Cardiospermum in the New World: A. serjaniae Henn. 1896, A. cardiospermophilum Speg. 1909 (= A. serjaniae Speg. 1925) and A. reichei Dietel 1914. Aecidium uredinoides Henn. may not grow on a sapindaceous host but a member of Annonaceae (Sydow and Sydow 1924). Aecidium serjaniae Henn. was excluded from rust fungi by Sydow and Sydow (1924). The Aecidium issued in 'Sydow, Uredineen' no. 2197 under that name is of uncertain identity, therefore, but it has been found to be different from the present species. Aecidium reichei and A. cardiospermophilum are different from the present rust as well according to the descriptions given by Sydow and Sydow (1924) and Lindquist (1982).

Acknowledgements We thank Anja Rössel and Elisabeth Uhlmann for companionship and assistance in the field, the German Ministry of Education and Research (BMBF) for funding the field stays of R.B., and the Western and Northern Cape Nature Conservation Boards in South Africa for issuing collecting and export permits. Loans of specimens granted by the curators and directors of B, HBG, PDD, PREM, PUR and VPRI are gratefully acknowledged. Roger Peterson and an unknown reviewer are thanked for helpful corrections and comments on the manuscript.

\section{References}

Arnold TH, De Wet BC (eds) (1993) Plants of southern Africa: Names and distribution. Memoirs of the Botanical Survey of South Africa no. 62. The National Botanical Institute, Pretoria, South Africa

Barreto RW, Evans HC (1995) Mycobiota of the weed Cyperus rotundus in the state of Rio de Janeiro, with an elucidation of its associated Puccinia complex. Mycol Res 99:407-419

Berndt R (2008a) The rust mycobiota of southern Africa: species richness, composition and affinities. Mycol Res 112:463-471

Berndt R (2008b) The rust fungi (Uredinales) on ferns in South Africa. Mycol Prog 7:7-19

Berndt R (2010) The Puccinia species of Berkheya (Asteraceae) with description of four new species. Mycologia 102:1437-1449

Berndt R, Uhlmann E (2006) New species, reports, observations and taxonomical changes of southern African rust fungi. Mycol Prog $5: 154-177$

Buriticá P (1991) Familias del orden Uredinales con ciclo de vida completamente reducido. Rev Acad Colomb Cienc Exactas 18:131-148

Buriticá P, Hennen JF (1980) Pucciniosireae (Uredinales, Pucciniaceae) Flora Neotropica monograph no. 24. The New York Botanical Garden, New York, USA

Castellani E, Ciferri R (1937) Prodromus mycoflorae africae orientalis italicae. Biblioteca Agraria Coloniale, Istituto Agricolo Coloniale Italiano, Firenze, Italy

Castellani E, Ciferri R (1950) Mycoflora erythraea, somala et aethiopica - Suppl. I. Atti dell' Istituto Botanico della Universitá di Pavia, Laboratorio Crittogamico (suppl.), Serie 5, vol. H: $1-51$
Crous PW, Rong IH, Wood A, Lee S, Glen H, Botha W, Slippers B, de Beer WZ, Wingfield MJ, Hawksworth DL (2006) How many species of fungi are there at the tip of Africa? Stud Mycol 55:13-33

Cummins GB (1945) Description of tropical rusts - VII. Bull Torrey Bot Club 72:205-222

Cummins GB (1952) Uredinales from various regions. Bull Torrey Bot Club 79:212-234

Cummins GB (1971) The rust fungi of cereals, grasses and bamboos. Springer, New York

Dianese JC, Medeiros RB, Santos LTP, Furlanetto C, Sanchez M, Dianese AC (1993) Batistopsora gen. nov. and new Phakopsora, Ravenelia, Cerotelium, and Skierka species from the Brazilian cerrado. Fitopatol Bras 18:436-450

Dietel P (1893) Sphaerophragmium dalbergiae n. sp. Hedwigia $32: 30-32$

Doidge EM (1927) A preliminary study of the South African rust fungi. Bothalia 2:1-228

Doidge EM (1939) South African rust fungi, III. Bothalia 3:487512

Doidge EM (1941) South African rust fungi, IV. Bothalia 4:229236

Doidge EM (1948) South African rust fungi, V. Bothalia 4:895918

Doidge EM (1950) The South African fungi and lichens to the end of 1945. Bothalia 5:1-1094

Gäumann E (1959) Die Rostpilze Mitteleuropas. Büchler, Bern

Gjærum HB (1974) Uromyces anthyllidis and Phakopsora zizyphi-vulgaris new to the Cape Verde Islands. Vieraea 3:100-102

Gjærum HB (1984) East African rusts (Uredinales), mainly from Uganda. 2. On Cyperaceae. Mycotaxon 20:53-63

Gjærum HB (1985) East African rusts (Uredinales), mainly from Uganda. 4. On families belonging to Apetalae and Polypetalae. Mycotaxon 24:237-273

Gjærum HB (1990a) Puccinia isolepidis, a new cyperaceous rust species. Lidia 3:19-21

Gjærum HB (1990b) Uromyces cypericola, a new rust species in the Cyperaceae. Lidia 3:22-24

Gjærum HB (1998) Rust fungi from various countries. II. Agarica 15:149-153

Gjærum HB, Namaganda M, Lye KA (2003) Additions to the rust flora of Uganda. Lidia 6:33-61

Goldblatt P, Manning J (2000) Cape Plants. A conspectus of the Cape flora of South Africa. Strelitzia 9:1-743

Hennings P (1891) Fungi africani. Bot Jahrb Syst 14:337-373

Hiratsuka Y (1973) The nuclear cycle and the terminology of spore states in Uredinales. Mycologia 65:432-443

Hiratsuka Y, Cummins GB (1963) Morphology of the spermogonia of the rust fungi. Mycologia 55:487-507

Holmgren PK, Holmgren NH, Barnett LC (1990) Index herbariorum, Part I, 8th edn. The New York Botanical Garden, New York

Jackson HS (1926) The rusts of South America based on the Holway collections - I. Mycologia 18:139-162

Jennings DM, Ford-Lloyd BV, Butler GM (1989) An aniline blue squash technique for observation of urediniospore germ pores. Mycol Res 92:230-231

Jørstad I (1956) Reliquiae Lagerheimianae - African Uredinales. Ark Bot 3(ser. 2):563-598

Kern FD (1919) North American rusts on Cyperus and Eleocharis. Mycologia 11:134-147

Klebahn H (1914) Pilze III: Uredineen. In: Kryptogamenflora der Mark Brandenburg. Vol. Va. Gebr. Bornträger, Leipzig

Lindquist JC (1982) Royas de la República Argentina y zonas limítrofes. Instituto Nacional de Tecnología Agropecuaria, Colección Científica vol. 20. Buenos Aires, Argentina

Lohsomboon P, Kakishima M, Ono Y (1994) A monograph of Sphaerophragmium. Mycol Res 98:907-919 
Marchal É, Steyaert R-L (1929) Contribution à l'étude des champignons parasites des plantes au Congo Belge. Bull Soc R Bot Belgique 61 (2. ser. vol. 11):160-169

Mayor E (1914) Contribution à l'étude des Urédinées de Colombie. Mém Soc Sci Nat Neuchâtel 5:442-599

Mayor E, Terrier C (1957) Excursions mycologiques en Corse. Rev Mycol Paris 22:113-129, + 1 plate

Mayor E, Viennot-Bourgin G (1951) Contribution à la connaissance des micromycètes de la Côte-d'Ivoire. Bull Soc Mycol Fr 67:113-139

McAlpine D (1906) The rusts of Australia. The Government Printer, Melbourne, Australia

Mennicken M, Oberwinkler F (2004) A contribution to the rust flora (Uredinales) of southern Africa, with an emphasis on South Africa. Mycotaxon 90:1-28

Mennicken M, Maier W, Oberwinkler F (2005) A contribution to the rust flora (Uredinales) of southern Africa, with an emphasis on Namibia. Mycol Prog 4:55-75

Monoson HL (1974) The genus Sphaerophragmium. Mycologia 66:791-802

Muasya AM, 6 coauthors (2009) Phylogeny of Cyperaceae based on DNA sequence data: Current progress and future prospects. Bot Rev 75:2-21

Potter D, 10 coauthors (2007) Phylogeny and classification of Rosaceae. Plant Syst Evol 266:5-43

Ragunathan AN, Ramakrishnan K (1973) Rust fungi of Madras state. VII. Kuehneola, Hamaspora, Phragmotelium, Phragmidium,
Diorchidium, Ravenelia, Hapalophragmium and Nyssopsora. Mysore J Agric Sci 7:73-86

Sydow H, Sydow P (1903) Neue und kritische Uredineen. Ann Mycol $1: 324-334$

Sydow P, Sydow H (1915) Monographia Uredinearum. Vol. III. Pucciniaceae (excl. Puccinia et Uromyces). Gebr. Bornträger, Leipzig, Germany

Sydow P, Sydow H (1924) Monographia Uredinearum. Vol. IV. Uredineae imperfectae. Gebr. Bornträger, Leipzig, Germany

Viennot-Bourgin G (1958) Urédinales d'Afrique ( $5^{\mathrm{e}}$ note). Urédinales de Côte-d'Ivoire ( $4^{\mathrm{e}}$ note). Uredineana 5:137-248

Viennot-Bourgin G (1959) Étude de micromycètes parasites récoltés en Guinée. Ann Inst Natl Agron 45:1-91

Whiteside JO (1966) A revised list of plant diseases in Rhodesia. Kirkia 5:87-196

Wood AR (2006) New and interesting records of southern African rust fungi (Uredinales). S Afr J Bot 72:534-543

Wood AR (2007) Rust fungi (Uredinales) on Grewia species (Tiliaceae) in South Africa, with Uredopeltis atrides comb. nov. the new name for Ravenelia atrides. Mycol Prog 6:9399

Wood AR, Crous PW (2005) Morphological and molecular characterization of Endophyllum species on perennial asteraceous plants in South Africa. Mycol Res 109:387-400

Zhuang J-Y (1988) Species of Puccinia on the Cyperaceae in China. Mycosystema 1:115-148 